\title{
The role of photoperiod on the initiation of the breeding season of the brushtail possum (Trichosurus vulpecula)
}

\author{
R. T. Gemmell ${ }^{1}$ and C. Sernia ${ }^{2}$ \\ Departments of ${ }^{1}$ Anatomy and ${ }^{2}$ Physiology and Pharmacology, University of Queensland, St Lucia, \\ 4067 Brishane, Queensland, Australia
}

\begin{abstract}
Summary. The role of photoperiod on the initiation of the breeding season of brushtail possums was investigated in possums housed in three light regimens: a short-day, a natural and a long-day photoperiod. Seven possums were housed in a natural photoperiod. Four possums were transferred to a short-day photoperiod (10 h light, $14 \mathrm{~h}$ dark) and eight possums to a long-day photoperiod (14 h light, $10 \mathrm{~h}$ dark) on 22 November, when the daylength was $13.34 \mathrm{~h}$. The first rises in plasma progesterone concentrations were observed on 9 January \pm 9 days $(n=4), 11$ March \pm 6 days $(n=7)$ and 6 May \pm 6 days $(n=8)$, for possums held in short-day, natural or longday photoperiods respectively. Similarly, births were observed on 12 January and 14 February in the short-day group, from 3 March to 8 May for the natural photoperiod group, and from 5 May to 8 August for the long-day group. These results suggest that photoperiod is important in the timing of the breeding season. However, annual breeding will commence in a nonstimulatory long-day photoperiod. Thus a long-day photoperiod does not prevent breeding activity.
\end{abstract}

Keywords: seasonal breeding; daylength; marsupial; brushtail possum; captivity

\section{Introduction}

Marsupials can be separated into two groups on the basis of the presence or absence of embryonic diapause. Embryonic diapause occurs in most members of the family Macropodidae and in the honey possum, Tarsipes rostratus (Renfree, 1981; Russell, 1982). In these marsupials, ovulation and oestrus occur soon after parturition, yet the suckling by the newborn young prevents the full development of the corpus luteum and arrests the growing embryo at the unilaminar blastocyst stage. This mechanism, a lactational inhibition of reproduction, is known as lactational quiescence. Seasonal quiescence is not merely a prolongation of lactational quiescence but a response to environmental factors such as photoperiod (Tyndale-Biscoe \& Renfree, 1987). Most studies of seasonal breeding in marsupials have been carried out with two macropodid species: the tammar wallaby (Macropus eugenii) and Bennett's wallaby (Macropus rufogriseus). In these marsupials photoperiod is the major factor in the reactivation of the quiescent corpus luteum and the dormant blastocyst and in terminating seasonal quiescence (Loudon \& Curlewis, 1987; Tyndale-Biscoe \& Renfree, 1987).

The brushtail possum (Trichosurus vulpecula) is a member of the family Phalangeridae and, along with families Didelphidae, Peramelidae and Dasyuridae, does not display embryonic diapause. In South Australia and in the Northern Territory births of $T$. vulpecula have been recorded throughout the year (Pilton \& Sharman, 1962; Kerle, 1984; Sanderson \& O’Driscoll, 1986). In other regions of Australasia, births are more seasonal (Kerle, 1984). In Queensland, the Australian Capital Territory and New South Wales, a peak of births in March and April has been reported, followed by a second peak during September and October (Lyne \& Verhagen, 1957; Dunnet, 1964; Winter, 
1976; Gemmell et al., 1987). This second peak was not observed in New Zealand and Tasmania (Tyndale-Biscoe, 1955; Lyne \& Verhagen, 1957). Thus, the breeding season of $T$. vulpecula is variable within Australasia and the environmental cues that regulate the onset and duration of the breeding season are poorly understood.

The brushtail possum is a short-day breeder i.e. begins breeding as the days shorten. In Queensland, births in the breeding colony are first seen during March and continue throughout the year until November, no births being observed in December, January and February (Gemmell et al., 1987; Gemmell, 1987, 1990). Melatonin implants or housing in a short-day photoperiod $(10 \mathrm{~h}$ light: $14 \mathrm{~h}$ dark) have been shown to hasten the start of the breeding season (Gemmell, 1987, 1990) and those observations support the view that photoperiod influences the breeding activity of $T$. vulpecula. In this study, the influence of photoperiod on the initiation of the breeding season of $T$. vulpecula was investigated by comparing the breeding activity of female possums in a natural photoperiod with those kept in a long-day or short-day photoperiod.

\section{Materials and Methods}

\section{Animals and treatments}

Nineteen adult female possums that were known to have given birth previously were used in this study. Seven possums were housed in a natural photoperiod. Three or four female possums, with one adult male, were housed in each of two fully enclosed holding yards measuring $9 \times 3 \times 2 \mathrm{~m}^{3}$, and were supplied with running water, fruit and vegetables. The major portion of these two yards was open and the possums were thus kept in a natural photoperiod. The remaining 12 adult female possums were transferred from similar outside holding yards to light-controlled rooms on 22 November, 1989 when the daylength was $13.34 \mathrm{~h}$. The light-controlled room for the eight female possums held in a long-day photoperiod was divided into two sections by a chain wire partition. In each section, $3 \times 3 \times 4 \mathrm{~m}^{3}$, four female possums and one male were housed and supplied with water, fruit and vegetables. Light was supplied by one $40 \mathrm{~W}$ fluorescent tube. The level of illuminance measured from light reflected from the walls was $140 \pm 15 \mathrm{~lx}$ $(n=6)$. Light levels were determined with a National Digital Lux tester (Matsushita Electric Industrial Co. Ltd, Japan). Lights were turned on at 05:00 h and off at 19:00 h (14 h light, $10 \mathrm{~h}$ dark). The room had separate air intake and exhaust ducts which were baffled to prevent light leaks. Temperature was not controlled. The four possums held in a short-day photoperiod ( $10 \mathrm{~h}$ light, $14 \mathrm{~h}$ dark) were housed in another room under similar conditions (Gemmell, 1990). Lights were switched on at 07:00 $\mathrm{h}$ and off at 17:00 h.

\section{Blood samples}

Blood samples $(2 \mathrm{ml})$ were obtained once a week from the seven control possums, until a young was first observed in the pouch. Blood samples were obtained once a week from the four possums held in a short-day photoperiod, until a young was first observed in the pouch or until 1 May. Samples were obtained from the eight possums housed in a long-day photoperiod every two weeks from November to I May, and every week from I May until a young was first observed in the pouch or until 17 July. The size and morphology of the teats of the females were noted as these structures enlarged close to parturition. The date of birth of pouch young was determined either by observing the day of birth or estimating the age of pouch young from the length of the head and the total body weight according to the method described by Lyne \& Verhagen (1957).

\section{Progesterone assay}

Progesterone concentrations in $50-100 \mu$ plasma were determined by radioimmunoassay using the method described previously (Gemmell et al., 1987) using sheep anti-progesterone-1l-hemisuccinate-bovine serum albumin (Antiserum No. 334) kindly donated by R. I. Cox, CSIRO, Prospect. New South Wales, Australia. The anti-serum was highly specific for progesterone, the only significant crossreaction being with $11 \beta$-hydroxyprogesterone $(11.9 \%)$. The limit of sensitivity of the assay was $25 \mathrm{pg}$ per tube and at a progesterone concentration of $10 \mathrm{ng} \mathrm{m}{ }^{-1}$ the intraand interassay coefficients of variation were $10.5 \%(n=5)$ and $13.0 \%(n=10)$, respectively. The assay buffer blank was less than $0 \cdot 1 \mathrm{ng} \mathrm{ml}^{-1}$ and the efficiency of extraction was $85 \cdot 0 \%(n=10)$.

\section{Statistical analysis}

One-way analysis of variance was used to determine whether the mean day of first rise in progesterone concentration differed significantly across the three groups, that is short-day, natural and long-day photoperiods. 


\section{Results}

The first increase in plasma progesterone concentration greater than $5 \mathrm{ng} \mathrm{ml}{ }^{-1}$ occurred on the mean date of 9 January for the four possums held in a short-day photoperiod. One of the possums gave birth on 12 January and one on 4 February (Table 1). Possums 3 and 4 were displaying

Table 1. Reproductive events in the three groups of possums held in differing light regimens

\begin{tabular}{|c|c|c|}
\hline Photoperiod & $\begin{array}{l}\text { Mean day of first rise in } \\
\text { progesterone concentration } \\
\text { (over } 5 \mathrm{ng} \mathrm{ml}^{-1} \text { ) }\end{array}$ & $\begin{array}{l}\text { Mean day of } \\
\text { first birth }\end{array}$ \\
\hline $\begin{array}{l}\text { Short day } \\
\qquad(10 \mathrm{~h} \text { light: } 14 \mathrm{~h} \text { dark }) \\
n=4\end{array}$ & $\begin{array}{l}9 \text { Jan } \pm 9 \text { days }^{\mathrm{a}} \\
\text { range } 26 \text { Dec }-6 \text { Feb }\end{array}$ & $\begin{array}{l}12 \mathrm{Jan}, 4 \mathrm{Feb} \\
\text { (two possums did not give birth) }\end{array}$ \\
\hline $\begin{array}{l}\text { Natural photoperiod } \\
n=7\end{array}$ & $\begin{array}{l}11 \text { Mar } \pm 6 \text { days }^{\mathrm{a}} \\
\text { range } 26 \mathrm{Feb}-10 \mathrm{Apr}\end{array}$ & $\begin{array}{l}1 \text { Apr } \pm 10 \text { days } \\
\text { range } 3 \text { Mar- } 8 \text { May }\end{array}$ \\
\hline $\begin{array}{l}\text { Long day } \\
\qquad(14 \text { h light: } 10 \text { h dark) } \\
n=8\end{array}$ & $\begin{array}{l}6 \text { May } \pm 6 \text { days }^{\mathrm{a}} \\
\text { range } 3 \mathrm{Apr}-22 \text { May }\end{array}$ & $\begin{array}{l}5 \text { May, } I \text { and } 22 \text { Jun, } 8 \text { Aug } \\
\text { (4 possums did not give birth) }\end{array}$ \\
\hline
\end{tabular}

nonpregnant or oestrous cycles (Figs 1 and 4). Possum 2 had one nonpregnant cycle before giving birth on 4 February (Figs 1 and 4 ).

The mean date of the first rise in plasma progesterone concentration for the seven possums held in a natural photoperiod was 11 March and the mean date of the first births of the breeding season was 1 April (Table 1). All seven possums gave birth, possums 5, 6, 7 and 8 on the first ovulation of the breeding season and the other three possums displayed cyclic activity before becoming pregnant (Figs 2 and 4).

Only four of the eight possums held in the long-day photoperiod gave birth. Possums 12, 13, 14 and 17 gave birth on $5 \mathrm{May}, \mathrm{l}$ and 22 June and 8 August, respectively. The mean date of the first rise in progesterone concentration was 6 May (Table 1), although possums 16 and 19 only showed one slight increase in plasma progesterone concentration, 3.6 and $5.1 \mathrm{mg} \mathrm{ml}^{-1}$, respectively. The plasma progesterone profiles of possums 15, 17 and 18 indicated that several oestrous cycles had occurred during the period of observation (Fig. 3). Possums 18 and 19 died on 6 and 12 June, respectively. No obvious reasons for the deaths were observed.

One-way analysis of variance demonstrated that the mean day of first rise in progesterone concentration for each group was significantly different from every other group $(P<0.001)$ (Table 1).

\section{Discussion}

The breeding colony from which the possums in this study were selected has been observed from 1983 to 1989 and found to begin producing young between 9 March and 30 April (Gemmell, 1990). In this study, the seven possums kept outdoors in natural photoperiod bred at the expected time, giving birth between 3 March and 8 May. When housed in a short-day environment breeding occurred ahead of the natural photoperiod group, with one possum giving birth on 12 January and one on 4 February and the remaining two showing oestrous cycles. A similar outcome was observed previously, with births on 11 and 30 January, 17 February and 21 March in short-day 


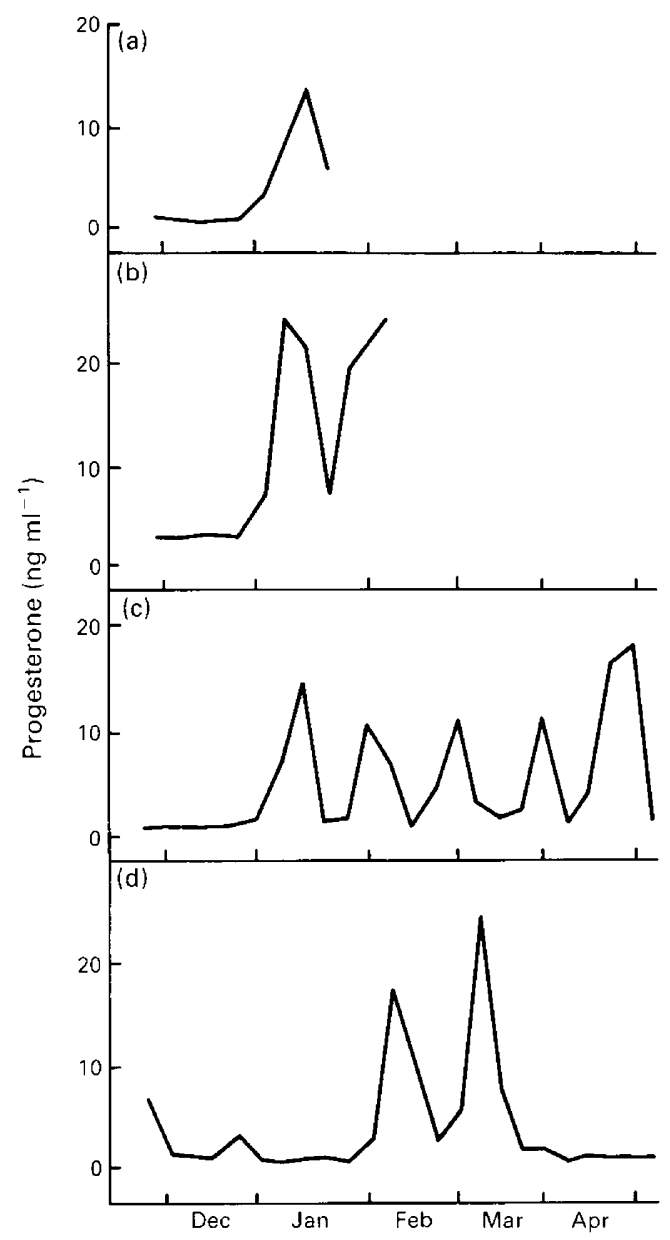

Fig. 1. (a-d) Plasma progesterone profiles of four possums held in a photoperiod of $10 \mathrm{~h} \mathrm{light:}$ 14 h dark (short days) on 22 November. (a) Date of birth was 12 January; (b) date of birth was 4 February; (c) and (d) were not pregnant.

conditions (Gemmell, 1990). Increasing the light period to $14 \mathrm{~h}$ delayed the onset of ovarian activity by nearly two months to 6 May \pm 6 days $(n=8)$. There are two possible explanations for this. The possums housed in a long-day photoperiod could have become refractory to the nonstimulatory photoperiod and ovulated. The second possibility is that the possums have a circannual rhythm and the nonstimulatory photoperiod cannot inhibit the breeding activity that occurs annually. Nevertheless, the data from this present study support the view that possums use decreasing photoperiod to initiate their breeding season.

In sheep, as in possums, breeding occurs naturally as daylength shortens (Legan \& Karsch, 1980; Wayne et al., 1988). When placed in a constant short-day photoperiod, sheep are stimulated to ovulate (Legan \& Karsch, 1980; Wayne et al., 1988) and breeding activity shows a circannual cycle when this photoperiod is maintained over several years (Robinson \& Karsch, 1988; Karsch et al., 1989). However, sheep differ from possums in that a constant long-day photoperiod does not delay ovarian activity beyond that seen in a natural photoperiod (Robinson et al., 1985). Thus both sheep and possums have a circannual reproductive rhythm that is synchronized by photoperiod, except that the circannual rhythm in possums is clearly more labile to the influence of photoperiod. 


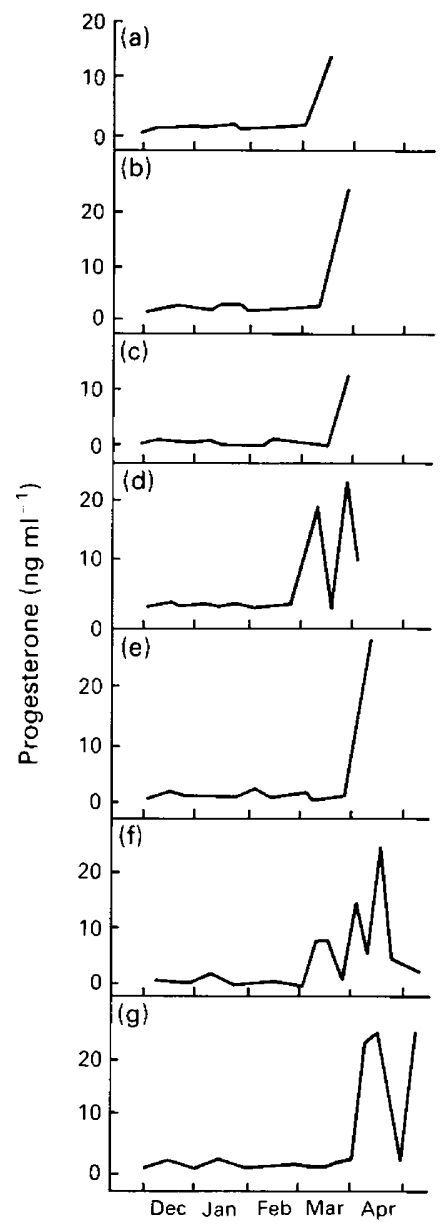

Fig. 2. Plasma progesterone profiles of seven possums held in a natural photoperiod. The date of birth was (a) 3 March; (b) 5 March; (c) 11 March; (d) 29 March; (e) 8 April; (f) 30 April and (g) 7 May.

Long-day breeders such as voles, rats, hamsters and deermice also change their breeding season in response to manipulation of photoperiod and if placed under appropriate laboratory conditions will show continuous breeding (see reviews by Zucker et al., 1980; Bronson, 1988). Sheep placed in a photoperiod of $12 \mathrm{~h}$ light: $12 \mathrm{~h}$ dark have also been reported to breed continuously (Radford, 1961; Jackson et al., 1990). Whether possums can also be induced to breed continuously by some suitable photoperiod regimen has not yet been investigated. An equatorial photoperiod needs to be tried since the experience with sheep indicates an almost total replacement of circannual breeding with continuous breeding (Jackson, 1990).

Whereas all possums in a natural photoperiod gave birth, those in either short or long daylengths showed a decline in the birth rate, in spite of the changes in plasma progesterone concentrations which indicated a return to oestrus. The reasons for this lowered fertility are unclear. A pre-existing state of low fertility in the females is an unlikely explanation, since only possums of proven fertility were included in this study. The male possum shows a seasonal pattern of plasma testosterone concentration (Gemmell et al., 1986) and the prostate enlarges sixfold during the breeding season, whereas the testes and epididymides remain unchanged (Gilmore, 1969). However, males housed in a nonstimulatory, that is, long-day photoperiod are fertile and were clearly so 


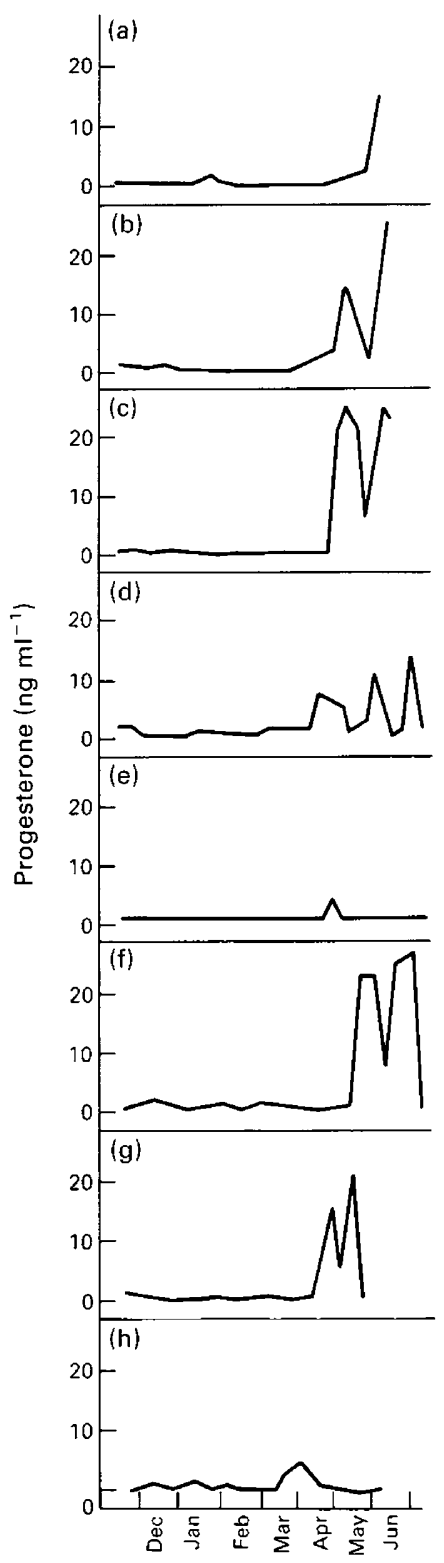

Fig. 3. Plasma progesterone profiles of eight possums held in a photoperiod of $14 \mathrm{~h}$ dark:10 h light (long days) on 22 November. The date of birth was (a) 5 May; (b) 1 June; (c) 22 June and (f) 8 August; (g) and (h) possums died on 6 June and 12 June, respectively, and (d) and (e) did not give birth.

in this study because all groups, which consisted of three to four females housed with a single male possum, had females that gave birth. Nevertheless, housing males in photoperiod rooms may reduce their fertility and examination of the prostate and testes of these possums may assist in explaining this reduction in production of young. It is possible that oestrous behaviour was absent in the nonpregnant possums; perhaps these possums were displaying 'silent' oestrus, akin to those reported in sheep at the beginning of their breeding season (Walton et al., 1977). Further studies are required to determine the cause of the decreased fertility in possums kept in artificial photoperiods. 


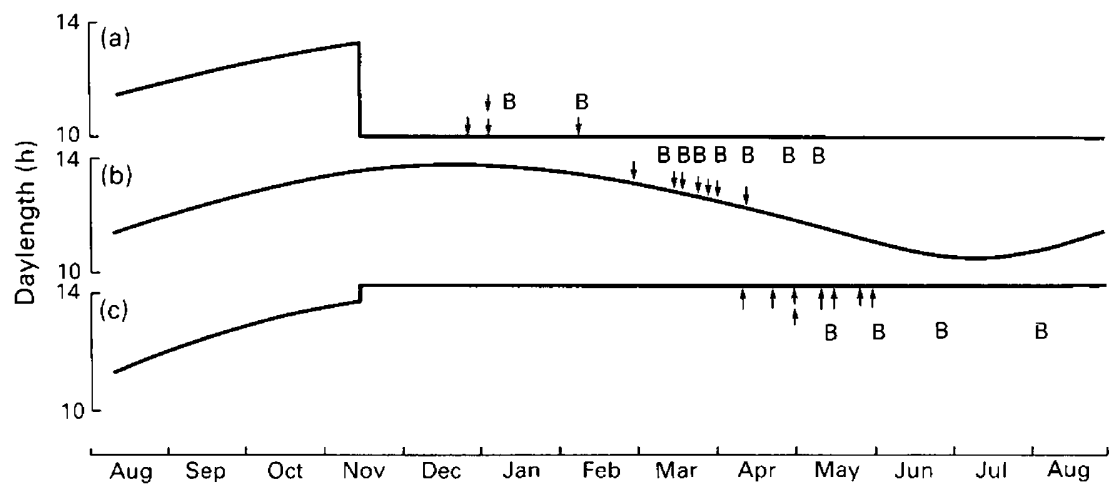

Fig. 4. Summary of the reproductive responses of possums to (a) short-day photoperiod, (b) natural photoperiod and (c) long-day period. Arrows indicate the first rise in progesterone concentration. B: birth.

As stated previously, possums held in a long-day photoperiod ovulate and give birth. If this activation of the reproductive processes of the possum is due to refractoriness, then presumably the possum will continue to ovulate continuously. If the reactivation is due to a circannual rhythm then the possum should ovulate and give birth for up to 9 months and then enter a period of anoestrus. The possums in this study, housed in short-day and long-day photoperiods, will be monitored for several years to obtain this information.

The authors thank the Australian Research Committee for financial support.

\section{References}

Bronson, F.H. (1988) Seasonal regulation of reproduction in mammals. In The Physiology of Reproduction, pp. 1831-1871. Eds E. Knobil \& J. Neill. Raven Press Ltd, New York

Dunnet, G.M. (1964) A ficld study of local populations of brush-tailed possum Trichosurus vulpecula in eastern Australia. Proceedings of the Royal Society 142, 665669 .

Gemmell, R.T. (1987) The effect of melatonin and the removal of pouch young on the seasonality of births in the marsupial possum. Trichosurus vulpecula. Journal of Reproduction and Fertility 80, 301-307.

Gemmell, R.T. (1990) The influence of daylength on the initiation of the breeding season of the marsupial possum. Trichosurus vulpecula. Journal of Reproduction and Fertility 88, 605609.

Gemmell, R.T., Cepon, G. \& Barnes, A. (1986) Weekly variations in weight and plasma testosteroneconcentrations in the captive male possum, Trichosurus vulpecula. General and Comparative Endocrinologv 62, 1-7.

Gemmell, R.T., Hughes, R.L. \& Jenkin, G. (1987) Comparative studies on the hormonal profiles of progesterone and prostaglandin $\mathrm{F}$ metabolite in the possum, Trichosurus vulpecula. In Possums and Opossums, Studies in Evolution, pp. 279-291. Ed. M. Archer. Royal Zoological Society of New South Wales and Surrey Beatty and Sons, Sydney.
Gilmore, D.P. (1969) Seasonal reproductive periodicity in the male brush-tail possum (Trichosurus vulpecula). Journal of Zoology (London) 157, 75-98.

Jackson, G.L., Jansen, H. \& Kao, C. (1990) Continuous exposure of Suffolk ewes to an equatorial photoperiod disrupts expression of the annual breeding season. Biology of Reproduction 42, 63-73.

Karsch, F.J., Robinson, J.E., Woodfill, C.J.I. \& Brown, M.B. (1989) Circannual cycles of luteinizing hormone and prolactin secretion in ewes during prolonged exposure to a fixed photoperiod: evidence for an endogenous reproductive rhythm. Biology of Reproduction 41, 1034-1046.

Kerle, J.A. ( 1984) Variation in the ecology of Trichosurus: its adaptive significance. In Possums and Gliders, pp. 115 128. Eds A. Smith \& I. Hume. Australian Mammal Society and Surrey Beatty and Sons. Sydney.

Legan, S.J. \& Karsch, F.J. (1980) Photoperiodic control of season breeding in ewes: modulation of the negative feedback action of estradiol. Biology of Reproduction 23, $106 \mathrm{I}-1068$.

Loudon, A.S.I. \& Curlewis, J.D. (1987) Refractoriness to melatonin and short daylengths in early seasonal quiescence in the Bennett's wallaby (Macropus rufogriseus rufogriseus). Journal of Reproduction and Fertility 81, 543-552. 
Lyne, A.G. \& Verhagen, A.M.W. (1957) Growth of the marsupial Trichosurus vulpecula and a comparison with some higher mammals. Growth 21, 167-195.

Pilton, P.E. \& Sharman, G.B. (1962) Reproduction in the marsupial Trichosurus vulpecula. Journal of Endocrinology 25, 119-136.

Radford, H.M. (1961) Photoperiodism and sexual activity in Merino ewes. II. The effect of equinoctial light on sexual activity. Australian Journal of Agricultural Research 12, 147-153.

Renfree, M.B. (1981) Embryonic diapause in marsupials. Journal of Reproduction and Fertility Supplement 29, $67-78$

Robinson, J.E. \& Karsch, F.J. (1988) Timing the breeding season of the ewe: what is the role of daylength? Reproduction Nutrition Développement 28, 365-374.

Robinson, J.E., Wayne, N.L. \& Karsch, F.J. (1985) Refractoriness to inhibitory day lengths initiates the breeding season of the Suffolk ewe. Biology of Reproduction 32, 1024-1030.

Russell, E.M. (1982) Patterns of paternal care and parental investment in marsupials. Biological Reviews 57, 423-486.

Sanderson, K.J. \& O'Driscoll, M. (1986) Breeding season of brushtail possums, Trichosurus vulpecula (Marsupialia: Phalangeridae), in Adelaide. Australian Mammalogy 9, 139-140.
Tyndale-Biscoe, C.H. (1955) Observations on the reproduction and ecology of the brush-tail possum Trichosurus vulpecula Kerr (Marsupialia) in New Zealand. Australian Journal of Zoology 3, 162-184.

Tyndale-Biscoe, H. \& Renfree, M. (1987) Reproductive Physiology of Marsupials. Cambridge University Press, Cambridge.

Walton, J.S., McNeilly, J.R., McNeilly, L.S. \& Cunningham, G.F. (1977) Changes in concentrations of follicle-stimulating hormone, luteinizing hormone, prolactin and progesterone in the plasma of ewes during the transition from anoestrus to breeding activity. Journal of Endocrinology 75, 127-136.

Wayne, N.L., Malpaux, B. \& Karsch, F.J. (1988) How does melatonin code for daylength in the ewe: duration of nocturnal melatonin release for coincidence of melatonin with a light-entrained sensitive period? Biology of Reproduction 39, 66-75.

Winter, J.W. (1976) The behaviour and social organisation of the brushtail possum (Trichosurus vulpecula Kerr). PhD Thesis, University of Queensland, Brisbane.

Zucker, I., Johnston, P.G. \& Frost, D. (1980) Comparative physiological and biochronometric analyses of rodent seasonal reproductive cycles. Proceedings of Reproductive Biology 5, 102-133.

Received 21 May 1991 